\title{
Upaya Penggunaan Aplikasi Nike Training Club (NTC) untuk Meningkatkan Kelincahan (Agility) pada UKM Bola Basket STKIP Bina Mutiara
}

\author{
Faiz Faozi ${ }^{1}$, Irpan Abdurahman ${ }^{2}$, Rafdlal Saeful Bakhri ${ }^{3}$, Chairul Umam \\ Ramadhan $^{4}$, Moch Latif ${ }^{5}$, Debi Krisna Irawan ${ }^{6}$ \\ Pendidikan Jasmani Kesehatan dan Rekreasi, STKIP Bina Mutiara Sukabumi ${ }^{1,2,3,4,5,6}$ \\ faizfaozi@gmail.com¹, irpanabd@gmail.com², madal.rafhael@gmail.com ${ }^{3}$, \\ umamlism@gmail.com ${ }^{4}$, mochammadlatif94@gmail.com ${ }^{5}$, debikrisna27@gmail.com 6
}

\begin{abstract}
Abstrak
Kelincahan (agility) menjadi salah satu faktor terpenting dalam olahraga bola basket. Karena dengan kelincahan yang dimiliki oleh setiap pemain, pemain tersebut bisa melewati lawanlawannya dalam pertandingan. Maka dari itu dibutuhkan bentuk latihan yang dapat meningkatkan kelincahan (agility) dari pemain tersebut, kemudian peneliti mencoba penggunaan aplikasi smartphone yaitu Nike Training Club untuk meningkatkan kelincahan (agility) mahasiswa yang mengikuti unit kegiatan mahasiswa (ukm) bola basket. Penelitian ini bertujuan untuk mengetahui pengaruh penggunaan aplikasi Nike Training Club (NTC) terhadap peningkatan kelincahan (agility) pada unit kegiatan mahasiswa (ukm) bola basket STKIP Bina Mutiara. Jenis penelitian yang digunakan dalam penelitian ini adalah eksperimen dengan desain penelitian menggunakan One Group Pretest Posttest Design. Instrumen yang digunakan Illinois Agility Test untuk mengukur kelincahan (agility). Subjek penelitian ini adalah mahasiswa yang mengikuti ukm bola basket sebanyak 25 yang dipilih dengan menggunakan sampel jenuh. Hasil analisis data menunjukan adanya peningkatan kelincahan (agility) pada mahasiswa yang mengikuti ukm bola basket setelah mendapatkan perlakuan atau treatment dengan menggunakan aplikasi Nike Training Club, terbukti dari nilai $\mathrm{t}=10.115$ dan nilai Sig. $0,000<0.05$ artinya memiliki pengaruh yang signifikan dengan rata-rata pretest 19.40 dan rata rata posttest 15.80 dan melihat dari nilai norma perhitungan Illinois agility test memperoleh nilai above average atau bisa dikatakan mendapatkan nilai diatas rata-rata. Berdasarkan hasil tersebut maka dapat diambil kesimpulan untuk penelitian ini yaitu terdapat peningkatan dari penggunaan aplikasi Nike Training Club terhadap kelincahan (agility) pada unit kegiatan mahasiswa (ukm) bola basket STKIP Bina Mutiara.
\end{abstract}

Kata Kunci: Nike Training Club (NTC); Kelincahan (Agility); Bola Basket; Mahasiswa

\section{Abstract}

Agility is one of the most important factors in basketball. Because with the agility possessed by each player, the player can pass his opponents in the match. Therefore, a form of exercise is needed that can improve the agility of the player, then the researchers tried to use a smartphone application, namely the Nike Training Club to improve the agility of students who participated in the student activity unit (UKM) basketball. This study aims to determine the effect of using the Nike Training Club (NTC) application on increasing agility in the basketball student activity unit (UKM) STKIP Bina Mutiara. The type of research used in this study is an experimental research design using One Group Pretest Posttest Design. The instrument used by the Illinois Agility Test is to measure agility. The subjects of this study were 25 students who took part in basketball SMEs who were selected using a saturated sample. The results of data analysis showed an increase in agility (agility) in students who took part in SME basketball after getting treatment or treatment using the Nike Training Club application, as evidenced by the $t$ value $=10,115$ and the Sig value. $0.000<0.05$ means that it has a significant effect with an average pre-test of 19.40 and an average of post-test of 15.80 and judging from the value of the Illinois agility test calculation norm, it obtains a value above average or it can be said to get a value above the average. Based on these 
results, it can be concluded for this study that there is an increase in the use of the Nike Training Club application on agility in STKIP Bina Mutiara basketball SMEs.

Keywords: Nike Training Club (NTC); Agility; Basketball; Student

\section{PENDAHULUAN}

Olahraga secara keseluruhan sangat berguna untuk kesehatan, karena dapat meningkatkan kepuasan pribadi dan mengurangi penurunan status kesehatan seseorang karena penuaan, penyakit dan cuaca. Menurut (Husdarta, 2011) menyatakan bahwa "olahraga merupakan kegiatan otot yang energik dan dalam kegiatan itu atlet memperagakan kemampuan gerakannya atau performa" Olahraga terdiri dari sekian banyak ragam antara lain olahraga perorangan serta olahraga beregu. Contoh olahraga yang dicoba perorangan misalnya beladiri serta atletik, setelah itu olahraga yang tercantum dalam olahraga beregu semacam basket, voli, sepak bola serta futsal.

Iman Sodikun dalam (Sucipto, 2010) menyatakan bahwa "Bola basket termasuk kategori permainan yang kompleks gerakannnya, maksudnya gerakannya terdiri dari seluruh komponen gerakan yang terkoordinasi apik sehingga pemain bisa bermain baik". Artinya dalam permainan bola basket membutuhkan kondisi yang baik, menurut (Hidayat, 2014) komponen-komponen kondisi fisik yaitu "daya tahan, stamina, kelentukan, kelincahan, kekuatan, daya tahan, kecepatan, dan koordinasi". Maksudnya tiap pemain mesti memiliki komponen kondisi fisik yang baik, sehingga dapat menunjang penampilan dalam pertandingan bola basket.

Pada cabang olahraga bola basket kelincahan (agility) sangat diperlukan yakni untuk melewati lawan ataupun menghindari penjagaan lawan, sependapat dengan (Widiastuti, 2011) "kelincahan adalah kemampuan untuk mengubah arah atau posisi tubuh dengan cepat yang dilakukan bersamasama dengan gerakan lainnya". Komponen kondisi fisik kelincahan ini sangat dibutuhkan hampir pada setiap cabang olahraga, pada cabang olahraga bola basket atlet dituntut untuk bergerak lebih cepat dari lawan. Dengan metode demikian atlet bisa membebaskan diri dari kawalan lawan ataupun bisa mencari posisi dalam menyerang dengan cepat tanpa mampu diiringi oleh lawan, sehingga akan terbentuk banyak kesempatan untuk menghasilkan skor. Sependapat dengan yang dikemukakan oleh (Dawes. J \& Roozen, 2012) menjelaskan bahawa "olahraga seperti bola basket, football amerika, sepak bola sangat membutuhkan akselerasi, deselerasi, dan berubah arah. Permainan bola basket, perubahan arah sangat diperlukan seperti dalam situasi menyerang maupun bertahan, baik dengan bola maupun tanpa bola".

Kelincahan pula tidak cuma menciptakan kecepatan namun pula fleksibilitas yang baik dari persendian. Menurut (Harsono, 2015) "Kelincahan adalah kemampuan untuk mengubah arah dan posisi tubuh dengan cepat dan tepat pada waktu sedang bergerak, tanpa kehilangan keseimbangan dan kesadaran akan posisi tubuhnya". Selain itu (Nossek, 2002) berpendapat "Kelincahan adalah kemampuan untuk meningkatkan keterampilan secara baik dan untuk memakainya dengan cepat dan tepat menurut kebutuhan- kebutuhan yang ingin dicapai pada situasi yang berbeda-beda". Bisa disimpulkan dari pendapat tersebut kelincahan selaku sesuatu keterampilan gerak individu guna merubah posisi serta arah gerak secara cepat serta tepat dalam suasana yang dialami serta dihendaki dengan menyertakan komponen fisik lain yang menunjang proses tersebut. 
Permainan bola basket pastinya jadi salah satu permainan yang popular serta digemari oleh banyak orang, dan seringnya kompetisi terkait permainan tersebut dari tingkatan usia dini hingga dewasa. Selain itu permainan bola basket ini juga digemari dan berkembang di kampus-kampus, sehingga banyaknya mahasiswa yang mengikuti Unit Kegiatan Mahasiswa (UKM) bola basket. STKIP Bina Mutiara menjadi salah satu kampus yang selalu mengikuti kompetisi bola basket antar perguruan tinggi. Namun ketika peneliti melakukan observasi pada UKM bola basket STKIP Bina Mutiara tim pelatih UKM tersebut mengatakan banyak permasalahan saat melatih mahasiswa ini, salah satu permasalahan yang terpenting yakni komponen kondisi fisiknya terutama kelincahan (agility) pada mahasiswa di kampus ini. Kelincahan (agility) salah satu komponen terpenting dari kondisi fisik yang dibutuhkan dalam permainan bola basket khusunya untuk para mahasiswa yang mengikuti UKM bola basket. Karena dengan kelincahan (agility) seorang pemain dapat melewati beberapa pemain lawan dan mengubah arah secara efisien pada saat pertandingan. Sependapat dengan yang dikemukakan oleh (Oliver \& Meyers, 2009) "Relates specifically to an athlete's ability to efficiently change direction, referred to as 'planned agility". Selain itu (Conrad, 2014) mengatakan bahwa "Agility is an important skill for athletes in many sports including basketball, because the movements in basketball are complex so that an athlete needs agility". Tentunya kelincahan ini menjadi salah satu komponen terpenting yang harus dimiliki oleh mahasiwa, karena dengan kelincahan (agility) yang dimiliki oleh mahasiswa akan menunjang dalam permaianan bola basket. Artinya dari beberapa pendapat diatas perlu adanya bentuk latihan untuk melatih kelincahan (agility) mahasiswa pada permainan bola basket, tentunya dibutuhkan bentuk latihan yang efektif dan tidak mudah membuat mahasiswa jenuh melakukan latihan tersebut.

Bentuk latihan yang diterapkan dalam penelitian ini yaitu menggunakan aplikasi smartphone Nike Training Club (NTC). Aplikasi Nike Training Club (NTC) merupakan aplikasi latihan full-body yang melayani setiap tingkat kebugaran melalui audio dan video, selain itu Nike Training Club (NTC) mengantarkan fungsi latihan kebugaran ke tingkat berikutnya (Padmasekara, 2014). Nike Training Club (NTC) ialah aplikasi yang dirancang guna menunjang olahragawan mencapai seluruh tujuan latihan tanpa mesti menghabiskan waktu di tempat gym. Aplikasi ini pula ialah aplikasi yang memudahkan pemakainya cuma dengan unduh ataupun download di itunes serta playstore dengan free tanpa berbayar. Latihan Nike Training Club (NTC) ialah variasi dari bentuk-bentuk latihan daya tahan, yang latihannya berperan guna mobilitas, kekuatan, stamina, serta kelincahan. Artinya dari penjelasan diatas mengenai aplikasi Nike Training Club (NTC) dapat digunakan untuk melatih kelincahan (agility). Selain itu setiap orang dapat menggunakan aplikasi tersebut dimanapun berada, dan bisa melakukan bentuk latihan sesuai dengan kebuthan masing-masing dari setiap pengguna aplikasi tersebut. Adapun bentuk tampilan aplikasi Nike Training Club (NTC) adalah sebagai berikut.

\section{Gambar 1. Bentuk Tampilan Aplikasi Nike Training Club (NTC)}

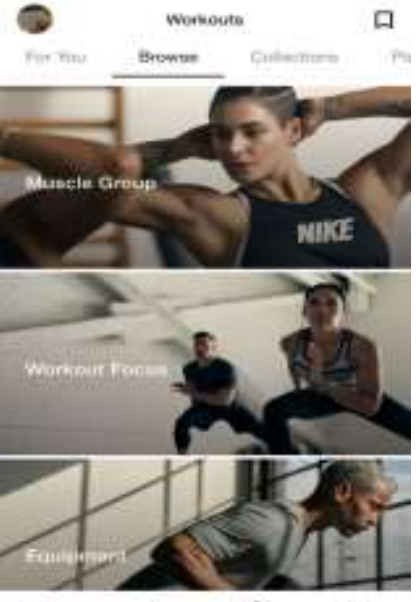

ㅇ.
Sumber : (Faozi, 2019)

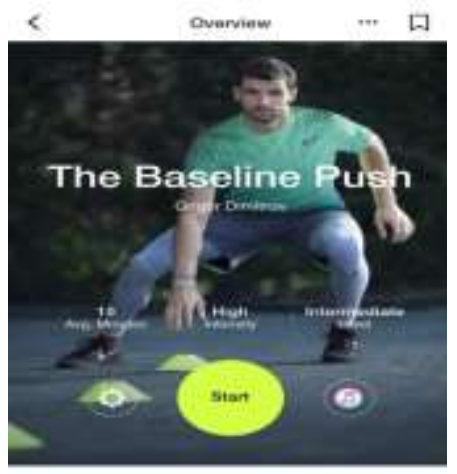

Good $\mathrm{Fer}$

-
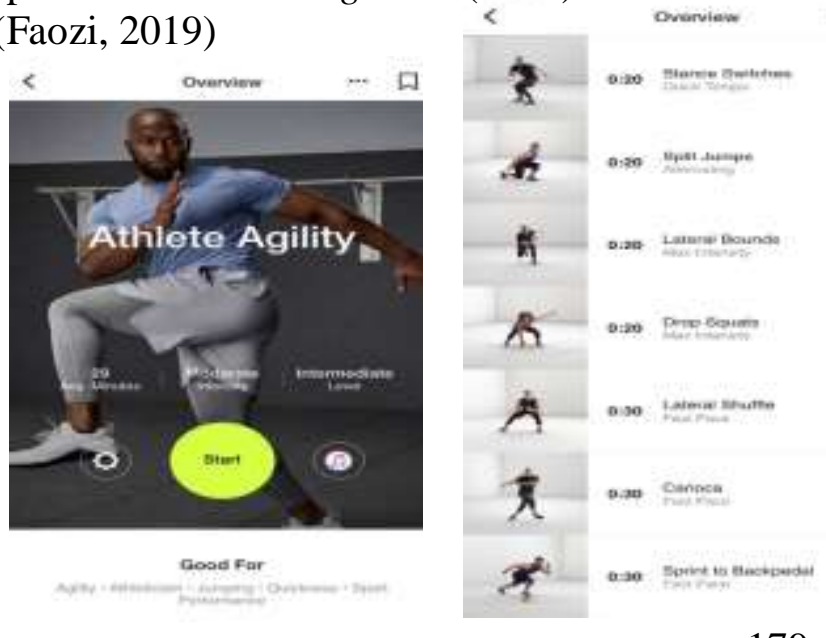
Dalam Nike Training Club (NTC) mencakup 150 sesi latihan termasuk 189 latihan yang membangun dasar-dasar kekuatan, kardio serta latihan inti yang dapat diakses secara gratis. Kemudian dalam penelitian ini peneliti memilih 12 sesi latihan yang sesuai dengan yang dibutuhkan dalam penelitian ini yaitu untuk meningkatkan kelincahan (agility), selain itu 12 sesi latihan ini yang nantinya akan diberikan pada proses pemberian treatment dalam penelitian, dan bentuk latihannya diantaranya yaitu, 1) the baseline push, 2) carioca, 3) agility run, 4) quick feet in and outs, 5) lateral shuffle, 6) lateral bound, 7) sprint to backpedal, 8) quick feet forward and back, 9) carioca in place, 10) quick feet lateral 3 step, 11) heel kick, dan 12) stance switches. Selain itu dalam tiap bentuk latihan dibantu dengan adanya audio dan video dalam aplikasi tersebut, sehingga dapat memudahkan bagi para pengguna aplikasi Nike Training Club (NTC) ketika tidak mengetahui gerakan dari bentuk latihan yang diinginkan. Selain itu terdapat beberapa penelitian terkait penggunaan aplikasi smartphone, (Faozi \& Rahmawati, 2019) Hasil analisis data menunjukan adanya peningkatan VO2max terhadap pemain futsal putri setelah mendapatkan perlakuan atau treatment dengan menggunakan aplikasi Nike Training Club. (Padmasekara, 2014) Hasil penelitian menunjukan Nike Training Club (NTC) lebih unggul daripada aplikasi Gorilla Workout namun, tidak ada perbedaan yang signifikan antar dua aplikasi. Aplikasi Nike Training Club (NTC) dan Instant Fitness sama efektifnya dengan kelompok RPM dan Wii Fit Plus. Kemudian penelitian yang dilakukan (Direito et al., 2015) Hasil penelitian tersebut adalah Aplikasi smartphone yang tersedia secara komersial berpengaruh terhadap peningkatan kebugaran dan aktivitas fisik pada orang muda.

Dari beberapa hasil penelitian terdahulu dapat disimpulkan bahwa penggunaan aplikasi smartphone dalam olahraga dapat membantu seseorang untuk memiliki kebugaran yang baik dan melatih keterampilan dalam olahraga. Selain itu dalam aplikasi Nike Training Club (NTC) memiliki bentuk variasi latihan untuk meningkatkan mobilitas, kekuatan, daya tahan, stamina, dan kelincahan. Sehingga penggunaan aplikasi Nike Training Club (NTC) ini dirasa penting dan dibutuhkan untuk meningkatkan kelincahan (agility) mahasiswa dalam permainan bola basket.

\section{METODE}

Metode yang digunakan dalam penelitian ini merupakan quasi experiment ialah penelitian eksperimen yang dilaksanakan pada satu kelompok saja yang dinamakan kelompok eksperimen tanpa terdapat kelompok pembanding ataupun kelompok kontrol (Maksum, 2013). Desain penelitian yang digunakan

dalam penelitian ini adalah one group pre test-post test. Adapun desain penelitian ditampilakan sebagai berikut:

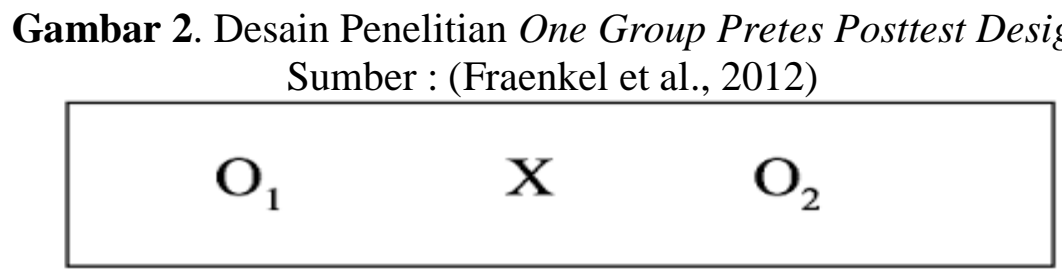

Keterangan:

$\mathrm{O}_{1}$ : Pretest (tes awal mengukur kelincahan (agility) dengan Illinois agility test)

$\mathrm{X}$ : Treatment (Aplikasi Nike Training Club)

$\mathrm{O}_{2}$ : Posttest (tes akhir mengukur kelincahan (agility) dengan Illinois agility test)

Pengumpulan data dilakukan dengan memberikan tes kelincahan (agility) yaitu dengan Illinois tes. Yang sebelumnya diberikan treatment dalam bentuk latihan kelincahan dengan menggunakan aplikasi Nike Training Club (NTC). Kemudian Instrumen adalah alat ukur yang digunakan untuk 
mengumpulkan data pada penelitian (Maksum, 2013). Instrumen yang dipakai untuk mengumpulkan data pada penelitian ini tes kelincahan (agility) dengan menggunakan Illinois Agility Test. Pelaksanaan dalam tes Illinois Agility Test adalah sebagai berikut 1) Testee menghadap ke lantai pada titik start, 2) Tester memberikan aba-aba mulai, kemudian teste memulai mengikuti alur yang sudah dibuat sampai ke finish, 3) Waktu akan dihitung pada saat peserta memulai start sampai melewati finish. Untuk lebih jelasnya perhatikan gambar berikut:

Gambar 3. Illinoist Agility Test

Sumber : (Mackenzie, 2011)

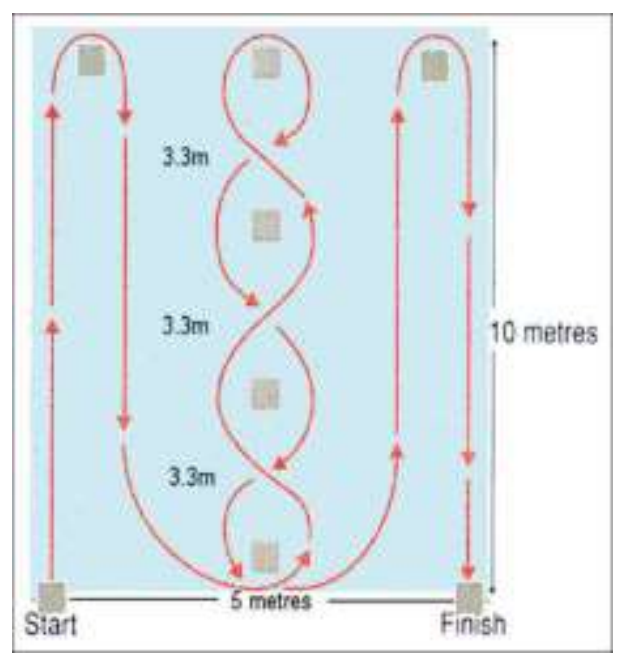

Kemudian dalam penilaian kelincahan dengan menggunakan alat tes illinois agility test, memiliki norma dengan satuan dalam detik. Sehingga nantinya bisa dilihat nilai dari setiap mahasiswa ketika melakukan tes kelincahan tersebut, adapun norma penilaian illinois agility test adalah sebagai berikut:

Tabel 1. Data Normatif Ilionis Agility Test dengan Satuan dalam Detik Sumber : (Mackenzie, 2011)

\begin{tabular}{ccc}
\hline Rating & Males (seconds) & Females (seconds) \\
\hline Excellent & $<15.2$ & $<17.0$ \\
Above Average & $15.2-16.1$ & $17.0-17.9$ \\
Average & $16.2-18.1$ & $18.0-21.7$ \\
Blow Average & $18.2-19.3$ & $21.8-23.0$ \\
Poor & $>19.3$ & $>23.0$ \\
\hline
\end{tabular}

Populasi dalam penelitian ini adalah keseluruhan mahasiswa yang mengikuti UKM bola basket di STKIP Bina Mutiara yaitu sebanyak 25 mahasiswa, yang dipilih dengan menggunakan sampel jenuh. Teknik sampling jenuh adalah teknik penentuan sampel dimana semua anggota populasi digunakan menjadi sampel (Maksum, 2013). Penelitian ini dilaksanakan di kampus STKIP Bina Mutiara. Penentuan pemilihan lokasi penelitian yaitu melihat beberapa sarana yang mendukung akan pelaksanaan penelitian tersebut.

Program penelitian tentunya harus terjadwal dan terencana dengan jangka waktu latihan pun menjadi suatu hal yang sangat penting serta dapat memiliki pengaruh terhadap hasil yang diperoleh. Pemberian treatment pada penelitian ini sebanyak 12 kali dan ditambah 2 kali pertemuan untuk mengambil data awal dan data akhir, merujuk pada penelitian yang dilakukan (Faozi \& Rahmawati, 2019) dengan menunjukan terdapat peningkatan VO2max pada pemain futsal putri setelah mendapatkan perlakuan atau treatment dengan penggunaan aplikasi Nike Training Club (NTC). Kemudian pelaksanaan penelitian menetapkan selama 6 minggu, dalam 1 minggu dilakukan 3 kali 
pertemuan untuk pemberian treatmen bentuk latihan menggunakan Nike Training Club (NTC). Selain itu 2 minggu digunakan mengambil data awal dan data akhir, sehingga pertemuan dalam penelitian sebanyak 14 kali pertemuan. Lamanya pemberian treatment tersebut, ditetapkan atas dasar pertimbangan jarak waktu yang mencukupi untuk bisa mengukur pengaruh dari suatu bentuk latihan serta merujuk kepada penelitian yang sudah dilakukan. Pelaksanaan latihan ini berpedoman pada teori yang dikemukakan oleh (Harsono, 2015) menyatakan bahwa "Sebaiknya latihan dilakukan tiga kali dalam seminggu dan diselingi dengan satu hari istirahat untuk memberikan kesempatan bagi otot untuk berkembang dan mengadaptasikan diri pada hari istirahat tersebut". Terkait dengan lama latihan yang diperlukan dalam penelitian selama enam minggu atau lebih, hal ini sejalan dengan pendapat (Harsono, 2015) yang mengatakan "Latihan kondisi fisik per-season yang intensif selama 6 sampai 10 minggu". Artinya dari beberapa pendapat tersebut bisa disimpulkan rencana dalam peneleitian yang akan dilakukan sesuai dengan teori yang dikemukakan dari para ahli.

Data yang didapat dari hasil pengumpulan data berupa data kuantitatif. Data tersebut selanjutnya dianalisis guna menjawab pertanyaan penelitian. Adapun analisis data yang dilakukan diantaranya adalah: 1). Uji normalitas data dilakukan melalui Kolmogorov smirnov-z;. 2). Uji homogenitas data menggunakan uji varians; dan 3). Uji hipotesis menggunakan uji Paired Sample $t$ test. Analisi data yang dilakukan dibantu dengan software SPSS versi 22.

\section{HASIL DAN PEMBAHASAN HASIL}

Berikut ini disajikan deskripsi data mahasiswa yang mengikuti UKM bola basket dengan perolehan nilai kelincahan (agility) adalah sebagai berikut:

Tabel 2. Deskripsi Data Kelincahan (Agility)

\begin{tabular}{lcccccc}
\hline Kelompok & N & Jenis & \multicolumn{2}{c}{ Pre-test } & \multicolumn{2}{c}{ Post-test } \\
& & & Rata-rata & Sd & Rata-rata & Sd \\
\hline Mahasiswa & 25 & Agility & 19.4 & 1.118 & 15.8 & 1.224 \\
\hline
\end{tabular}

Berdasarkan Tabel 2 diketahui nilai kelincahan mahasiswa bisa dilihat mengalami peningkatan. Seperti nilai rata-rata kelincahan dari pre-test 19.4/detik, kemudian nilai rata-rata post-test 15.8/detik mengalami peningkatan setelah diberikannya treatment latihan kelincahan menggunakan aplikasi Nike Training Club (NTC). Ini menunjukan bahwa latihan dengan menggunakan aplikasi Nike Training Club sebayak 12 kali pertemuan dalam satu bulan memberikan peningkatan terhadap kelincahan (agility).

Sebelum melakukan uji hipotesis terlebih dahulu dilakukan uji prasyarat yaitu uji normalitas dan homogenitas. Uji normalitas bertujuan untuk melihat apakah data yang diperoleh berasal dari populasi yang berdistribusi normal. Hasil uji normalitas data tes sebelum serta sesudah penerapan perlakuan berupa latihan menggunakan aplikasi Nike Training Club (NTC) adalah sebagai berikut:

Tabel 3. Uji Normalitas Kelincahan (Agility)

\begin{tabular}{ccccc}
\hline \multicolumn{2}{c}{ Kelompok } & Kolmorgov Smirnov & Sig & Kesimpulan \\
\hline \multirow{2}{*}{ Mahasiswa } & Pre-test & 1.106 & 0.211 & Normal \\
& Post-test & 1.029 & 0.265 & Normal \\
\hline
\end{tabular}

Untuk menentukan data berdistribusi normal atau tidak, dilihat dari nilai signifikansi (sig). Jika nilai signifikansi kurang dari 0.05 (Sig.<0.05) maka data berditribusi tidak normal. Jika nilai lebih dari 0.05 (Sig.>0.05) maka data berdistribusi normal. Dari hasil data pada Tabel 3 dapat dijelaskan 
hasil sebagai berikut: tabel uji normalitas diatas menunjukan untuk data pretest memperoleh nilai kolomogrov smirnov $=1.106$ dan siginifikansi $(\mathrm{Sig})=0.211>0.005$ maka dapat diartikan data berdistribusi normal. Untuk data posttest memperoleh nilai kolomogrov smirnov $=1.029$ dan siginfikansi $(\mathrm{Sig})=0.265>0.05$ maka dapat diartikan data berdistribusi normal .

Uji homogenitas bertujuan untuk melihat apakah data yang diperoleh berasal dari populasi yang memiliki variansi yang sama. Hasil uji data tes sebelum dan sesudah penerapan perlakuan berupa latihan menggunakan aplikasi Nike Training Club (NTC) adalah sebagai berikut:

Tabel 4. Uji Homogenitas Kelincahan (Agility)

\begin{tabular}{ccccc}
\hline \multicolumn{2}{c}{ Kelompok } & Levene Statistic & Sig & Kesimpulan \\
\hline \multirow{2}{*}{ Mahasiswa } & $\begin{array}{l}\text { Pre-test } \\
\text { Post-test }\end{array}$ & 0,029 & 0.866 & Homogen \\
\hline
\end{tabular}

Penentuan data bersifat homogen atau tidak dilihat dari nilai signifikansi (Sig). Jika nilai signifikansi kurang dari 0.05 (Sig.<0.05) maka data bersifat tidak homogen, akan tetapi jika nilai signifikansi lebih dari 0.005 (Sig.>0.05) maka data bersifat homogen. Berdasarkan tabel uji homogenitas pada Tabel 4 menunjukan data kelincahan yang menggabungkan antara hasil pre-test dan post-test kelompok eksperimen memperoleh nilai levene statistic $=0.029$ dan signifikansi $($ Sig. $)=0.866>0.005$ maka dapat diartikan data bersifat homogen. Setelah dilakukan uji normalitas dan homogenitas data, maka langkah selanjutnya adalah pengujian hipotesis. Berdasarkan hasil uji normalitas dan homogenitas data, uji hipotesis menggunakan uji statistika parametrik.

Uji hipotesis ini dilakukan untuk menjawab permasalahan yang diajukan dengan jawaban yang didapatkan dari data yang diperoleh dari lapangan. Untuk menguji data hasil tes awal dan tes akhir untuk mengetahui pengaruh dari pemberian treatment pada kelompok eksperimen dilakukan dengan Paired Sample t-test. Berikut ini disajikan uji Paired Sample t-test kelincahan (agility) yang diberi perlakuan latihan menggunakan aplikasi Nike Training Club (NTC), dengan menggunakan program Statistical Product and Service Solution (SPSS) adalah sebagai berikut:

Tabel 5. Hasil Uji Paired Sample t-test Kelincahan (Agility)

\begin{tabular}{ccccccc}
\hline \multicolumn{2}{c}{ Kelompok } & Rata-rata & Sig & t & $\boldsymbol{d} \boldsymbol{\text { Keterangan }}$ \\
\hline \multirow{2}{*}{ Ekspreimen } & Pre-test & 19.4 & \multirow{2}{*}{0.000} & \multirow{2}{*}{10.115} & \multirow{2}{*}{24} & Signifikan \\
& Post-test & 15.8 & & & \\
\hline
\end{tabular}

Berdasarkan hasil uji Paired Samples Test pada perlakuan dengan latihan menggunakan aplikasi Nike Training Club (NTC) menunjukan bahwa signifikansi pada kolom Sig. (2-tailed) menunjukan signifikansi $0,000<0,05$. Artinya, $H_{0}$ ditolak dan $H_{1}$ diterima, sehingga dapat disimpulkan bahwa terdapat pengaruh penggunaan Nike Training Club (NTC) pada peningkatan kelincahan (agility) pada UKM bola basket STKIP Bina Mutiara.

\section{PEMBAHASAN}

Berdasarkan dari hasil analisis data yang sudah dilakukan, data menunjukan bahwa terdapat pengaruh yang sigifikan. Bisa diartikan bahwa penelitian ini menunjukan bahwa penggunaan aplikasi "Nike Training Club" yang digunakan dalam latihan terbukti dapat meningkatkan kelincahan (Agility) pada UKM bola basket STKIP Bina Mutiara.

Berbagai aplikasi smartphone yang berkaitan dengan keolahragaan semakin banyak bermunculan (Bakhri et al., 2020). Beberapa aplikasi smartphone tersebut diantaranya pelacak kebugaran, monitor detak jantung, penghitug langkah, program latihan dan aplikasi pembinaan. Sejalan yang dikemukakan oleh (Direito et al., 2015) bahwa penggunaan aplikasi smartphone dengan 
tepat ternyata bisa meningkatkan aktivitas fisik sehingga berdampak pada meningkatnya aspek-aspek fisik, walaupun itu hanya memanfaatkan perhitungan langkah pada aplikasi smartphone. Dalam penelitian ini aplikasi yang digunakan adalah Nike Training Club (NTC) karena menurut (Adamakis, 2018) aplikasi tersebut memiliki banyak program aktivitas fisik didalamnya serta dari program yang ada didalamnya dapat meningkatkan kelincahan. Kemudian (Padmasekara, 2014) menyatakan bahwa "Nike Training Club merupakan aplikasi yang dirancang untuk membantu olahragawan mencapai semua tujuan latihan tanpa harus menghabiskan waktu di tempat gym”. Artinya aplikasi Nike Training $C l u b$ (NTC) ini memudahkan bagi pengguna untuk menggunakan dimana saja dan disesuaikan bentuk latihan yang diinginkan.

Hasil penelitian ini menunjukan bahwa penggunaan Nike Training Club (NTC) dapat meningkatkan kelincahan pada UKM bola basket STKIP Bina Mutiara. Hasil tersebut juga serupa dengan beberapa penelitian sebelumnya yang menggunakan aplikasi Nike Training Club (Faozi \& Rahmawati, 2019) aplikasi Nike Training Club yang digunakan dalam latihan terbukti mampu meningkatkan $\mathrm{VO}_{2} \mathrm{Max}$ pada pemain ekstrakurikuler futsal putri. Selain itu (Listiandi et al., 2020) menunjukan bahwa penggunaan Nike Training Club (NTC) adanya peningkatan daya tahan kardiovasler dan self-efficacy. Artinya dari kedua penelitian tersebut terkait penggunaan Nike Training Club (NTC) dapat meningkatkan komponen kondisi fisik bagi penggunanya, karena bentuk latihan didalam aplikasi Nike Training Club (NTC) yaitu variasi dari bentuk-bentuk latihan daya tahan, yang latihannya berfungsi untuk mobilitas, kekuatan, stamina, dan kelincahan (Padmasekara, 2014).

Bentuk latihan yang terdapat dalam aplikasi smartphone "Nike Training Club" yang digunakan berdasarkan pemaparan tersebut sesuai dengan tujuan latihan digunakan oleh mahasiwa yang mengikuti UKM bola basket. Menu dan tampilan pada aplikasi juga mudah untuk dipahami oleh para mahasiswa, setiap bentuk gerakan latihan ditampilkan dalam bentuk animasi gerakan, hal tersebut membuat mahasiswa lebih tertarik untuk menyelesaikan latihan sesuai dengan petunjuk yang tampil. Petunjuk mengenai gerakan-gerakan yang harus dilakukan selain didukung dengan animasi bergerak juga terdapat petunjuk suara, video gerakan dan narasi deskripsi.

Dapat disimpulkan secara keseluruhan hasil penelitian ini menunjukan bahwa penggunaan aplikasi smartphone Nike Training Club (NTC) dapat meningkatkan kelincahan (agility) mahasiswa yang mengikuti UKM bola basket. (Conrad, 2014) mengatakan bahwa "Agility is an important skill for athletes in many sports including basketball, because the movements in basketball are complex so that an athlete needs agility". Tentunya kelincahan ini menjadi salah satu faktor terpenting yang harus dimiliki oleh mahasiwa, karena dengan kelincahan (agility) yang dimiliki oleh mahasiswa akan menunjang dalam permainan bola basket.

\section{KESIMPULAN DAN SARAN}

Kesimpulan dalam penelitian ini adalah terdapat peningkatan atau pengaruh dari penggunaan Nike Training Club (NTC) pada kelincahan (agility) pada UKM bola basket STKIP Bina Mutiara Sukabumi. Dari penelitian ini dapat diberikan saran bagi peneliti selanjutnya sebagai berikut: 1) aplikasi yang digunakan dalam penelitian ini adalah Nike Training Club (NTC), maka untuk peneliti selanjutnya diharapkan menggunakan aplikasi lain yang menunjang dan biasa digunakan dalam olahraga. 2) aspek fisik yang digunakan dalam penelitian ini adalah kelincahan, maka untuk peneliti selanjutnya diharapkan meneliti aspek fisik yang lain.

\section{UCAPAN TERIMAKASIH}

Dalam Penelitian ini kami mengucapkan terima kasih kepada ketua STKIP Bina Mutiara Sukabumi yang selalu memberikan dukungan pada penulis dan kami mengucapkan terima kasih yang 
sebesar-besarnya kepada Kementerian Riset dan Teknologi / Badan Riset dan Inovasi Nasional yang telah memberikan dana hibah penelitian sehingga penelitian ini dapat terselenggara dengan baik.

\section{DAFTAR PUSTAKA}

Adamakis, M. (2018). Nike+ Training Club, an ultimate personal trainer: mobile app user guide. British Journal of Sports Medicine, 52(13), e2.

Bakhri, R. S., Nurjaman, D., Listiandi, A. D., Festiawan, R., \& Ginanjar, D. A. (2020). Pemanfaatan Aplikasi Smartphone: Meningkatkan Keterampilan Servis Atas Bola Voli. Jurnal Menssana, 5(2), 96-105.

Conrad, B. (2014). The Biomechanics of Basketball Agility. Sport Research Review, Spring(01), 18.

Dawes. J \& Roozen, M. (2012). Developing Agility and Quickness (Sport Performance Series). Human Kinetics.

Direito, A., Jiang, Y., Whittaker, R., \& Maddison, R. (2015). Smartphone apps to improve fitness and increase physical activity among young people: Protocol of the Apps for IMproving FITness (AIMFIT) randomized controlled trial. BMC Public Health, 15(1), 1-12. https://doi.org/10.1186/s12889-015-1968-y

Faozi, F., \& Rahmawati, D. (2019). Pengaruh Penggunaan Aplikasi Nike Training Club Terhadap Peningkatan Vo2max Pada Pemain Ekstrakurikuler Futsal Putri Man 1 Kabupaten Sukabumi. Biormatika: Jurnal Ilmiah Fakultas Keguruan Dan Ilmu Pendidikan, 5(02), 181-187. https://doi.org/10.35569/biormatika.v5i02.519

Fraenkel, J. R., Wallen, N. E., \& Hyun, H. H. (2012). How to Design And Evaluate Research in Education. McGraw-Hill, a business unit of The McGraw-Hill Companies, Inc., 1221 Avenue of the Americas, New York, NY 10020.

Harsono. (2015). Kepleatihan Olahraga. PT Remaja Rosdakarya.

Hidayat, S. (2014). Pelatihan Olahraga Teori dan Metodologi. Graha Ilmu.

Husdarta. (2011). Manajemen Pendidikan Jasmani. Alfabeta.

Listiandi, A. D., Kusuma, M. N. H., Budi, D. R., Hidayat, R., Bakhri, R. S., \& Abdurahman, I. (2020). Pemanfaatan Aplikasi Smartphone untuk Meningkatkan Daya Tahan. Jendela Olahraga, 05(2), 9-17.

Mackenzie, B. (2011). 101 Performance Evaluation Test. Jonathan Pye.

Maksum, A. (2013). Metodologi Penelitian Dalam Olahraga. Unesa University Press.

Nossek, J. (2002). General Theory of Training, National Instituet for Sport. Press Logos.

Oliver, J. L., \& Meyers, R. W. (2009). Reliability and generality of measures of acceleration, planned agility, and reactive agility. International Journal of Sports Physiology and Performance, 4(3), 345-354. https://doi.org/10.1123/ijspp.4.3.345

Padmasekara, G. (2014). Fitness apps, a Valid Alternative to the Gym: a pilot study. Journal of Mobile Technology in Medicine, 3(1), 37-45. https://doi.org/10.7309/jmtm.3.1.6

Sucipto. (2010). Permainan Bola Basket. UPI FPOK.

Widiastuti. (2011). Tes dan Pengukuran Olahraga. PT. Bumi Timur Jaya. 